\title{
A Brief Review on Changes in Air Pollution Scenario over South Asia during COVID-19 Lockdown
}

\section{Aerosol and Air Quality Research}

Special Issue:

Special Issue on COVID-19 Aerosol Drivers, Impacts and Mitigation (XII)

\author{
Manisha Mishra, U.C. Kulshrestha*
}

School of Environmental Sciences, Jawaharlal Nehru University, New Delhi - 110067, India

ABSTRACT

In general, the lockdown to prevent the outbreak of COVID-19 pandemic has resulted in a better quality of air across the world. The concentrations of both particulate and majority of gaseous pollutants were decreased drastically due to total shutdown of outdoor activities in the initial phase. This has resulted in up to $50 \%$ reduction in the air quality index (AQI) over South Asian megacities. A significant reduction was observed over most polluted ranked cities in South Asia like Delhi (41\%), Dhaka (16\%), Kathmandu (32\%), Colombo (33\%) including Islamabad and Kabul. A major decrease was also observed in the gaseous pollutants like $\mathrm{CO}, \mathrm{NO}_{2}$, and $\mathrm{SO}_{2}$. The strict lockdown provided an opportunity to the relevant authorities to reassess the large-scale transport and industrial sectors to avoid undue emissions of harmful pollutants. The present analysis suggests that there is a need of controlled emissions of air pollutants with reference to the lockdown values of 'New Normal', and to switch over to the cleaner fuel technology options at the earliest possible. There is a need to constitute an Inter-state agency to monitor transboundary and long-range transport of pollution across south Asia. Finally, a holistic approach for maintaining balance between 'need and greed' for energy and resource consumption is needed which can provide us the sustainable atmosphere and healthy air quality throughout the region.

Keywords: COVID-19, Pandemic, South Asia, Air Quality Index, Fine particulates

\section{INTRODUCTION}

Air quality deterioration poses a challenge for sustainability and environmental health issues in South Asian region. The threat to air quality is both due to natural as well as anthropogenic activities. Particulates such as mineral dust, bioaerosols, sea salts etc. and gasses like $\mathrm{CO}, \mathrm{SO}_{2}$, $\mathrm{NH}_{3}$, and $\mathrm{H}_{2} \mathrm{~S}$ are continuously released into the atmosphere through natural phenomena, e.g., vegetation decay, volcanic activity, and forest fires. Besides this, fresh air gets severely polluted through multi-fold emission of tiny harmful particles and gases from various human activities which have much more pronounced impact on the environment. Multiple sources of air pollution, such as automobile exhaust, smoke, particulates and heavy metal emission from industries, radioactive substances, biomass burning, etc., are the key drivers of degrading air quality. Effect of air pollutants on human health is very complex and one of the most widely studied topic in air pollution (Janssen et al., 2011; Cohen et al., 2017; Pani et al., 2020). Chronic exposure to air pollutants can cause a variety of respiratory illness, asthma and at a certain level, it can also induce lung cancer and cardiovascular disease in humans (Schraufnagel et al., 2019). Moreover, exposure to air pollution induces oxidative stress, damages the immune system, and also lowers the host's ability and resistance to viral infections (Babu et al., 2020). A study of the SARS epidemic in China has suggested that infected people were more likely to die if their locality had a poor-quality of air (Cui et al., 2003). Thus, air pollution has a direct impact on human health conditions. The global burden of disease (2017), for example, pointed out that in India about one million people die annually due to air pollution. Moreover, a recent study by the UNICEF (United Nation International Children's Emergency Fund) has demonstrated that children under oneyear age and living in the polluted environment are more prone to experience their brain damage 
(Grandjean, 2013). In the city of Dublin in 1980s, having observed the deterioration in survival rates of patients admitted to city hospital, the administration prompted the city to ban the most polluting types of coal (Grahame et al., 2014). So, based on the aforementioned aspects it is quite reasonable to agree that coupling of air pollution and human health under one policy would be beneficial.

The lockdown to prevent the COVID-19 outbreak was first implemented in Hubei province of China to restrict this contagious pandemic which was subsequently followed by many countries of the world. Initial phase of lockdown in most of the countries has led to strict restrictions on mobility, travel, economic and industrial activities except for the operation of essential services. A major highlight observed during the first phase of lockdown in China and Europe is the drastic decrease in air pollutants like $\mathrm{NO}_{2}, \mathrm{CO}$, black carbon (BC), particulate matter (PM) levels, etc. (Bao and Zhang, 2020). It is worthwhile mentioning that the lockdown has not only lowered down the incidence of COVID-19 but it has also led to a very significant reduction in environmental (air and water) pollution which could become a benchmark attainment, through policies and interventions by regulatory bodies, for many cities witnessing severe pollution episodes otherwise.

\section{GLOBAL OBSERVATIONS DURING COVID-19 LOCKDOWN}

Satellite data retrieved by various agencies like NASA, European Space Agency and other related institutions have reported a dramatic improvement in air quality during the period of COVID-19 lockdown as compared to the data compiled on same date in previous year (Venter et al., 2020). Restrictions in economic activities following the imposition of curfews by government authorities have led to the plummeted air pollution levels in most of the developed nations (Menut et al., 2020). Chinese megacities have observed reduction in $\mathrm{NO}_{2}$ levels as high as $53 \%$ during strict lockdown period owing to traffic emission changes (Wang et al., 2020). Similarly, up to $50 \%$ reduction in $\mathrm{NO}_{2}, \mathrm{BC}$ and $\mathrm{PM}$ levels observed over the capital cities of Iraq, Spain, Brazil, New Zealand, Italy, United States and Argentina (Baldasano, 2020; Bolaño-Ortiz et al., 2020; Cameletti, 2020; Hashim et al., 2021; Nakada and Urban, 2020; Patel et al., 2020; Shakoor et al., 2020; Shrestha et al., 2020). However, due to presence of natural sources of VOCs, reduction in $\mathrm{NO}_{2}$ and their complex interplay with meteorological factors, an increase in the formation of organic aerosols and ozone $\left(\mathrm{O}_{3}\right)$ has been notified in most of urban areas of these studies (Dhaka et al., 2020). Air Quality Index (AQI) and Aerosol Optical Depth (AOD) has also shown significant improvement as compared to pre-lockdown phase (Ranjan et al., 2020; Rodríguez-Urrego and Rodríguez-Urrego, 2020). NASA reports have also shown a twenty year low aerosol load over highly populated Indian subcontinent (NASA, 2020). In this context, the lockdown to prevent the pandemic COVID-19 has been seen as a never explored alternative, despite being temporary, to curb the air pollution related environmental issues over the major hotspots of the world (Kumar et al., 2020).

\section{LOCKDOWN AND AIR POLLUTION IN SOUTH ASIA}

South Asian region (India, Afghanistan, Pakistan, Nepal, Bhutan, Bangladesh and Sri Lanka) accounts for $40 \%$ population of Asia, making it among the world's most populous region. Since the onset of the COVID-19 most of the governments in the region have asked people to stay at home to combat spread of the pandemic. Measures of the lockdown include shutting down transportation, industrial centers, mining, and manufacturing and construction activities. The shutdown has stopped combustion of fossil fuel and biomass in huge quantity and thus reducing the emissions of gases and particles (Metya et al., 2020). Table 1 shows the major fuel types used in different capital cities (except Islamabad and Kabul owing to data availability limitations, however Karachi was taken as representative city for Pakistan) of South Asia, as estimated by recent version of IIASA's Greenhouse gas and Air pollution Interactions and Synergies (GAINS) model for the year 2020 (Höglund-Isaksson et al., 2020). Per capita coal combustion was observed to be highest in the Delhi and lowest in the Karachi city. However, biomass as fuel consumption, which is also a major emitter of BC, was found to be higher at Colombo and Kathmandu cities (Table 1). The maximum share of total fuel consumption in assessed capital cities was in Delhi $\left(180 \times 10^{6} \mathrm{GJ}\right.$ year $\left.^{-1}\right)$ owing to its high usage of coal as key fuel and greater population density. 
Table 1. Key fuel consumption per capita in the capital cities of South Asia.

\begin{tabular}{llllll}
\hline \multirow{2}{*}{ Fuel Type } & \multicolumn{5}{c}{ Energy use by key fuel type [Mega Joule year ${ }^{-1}$ per capita] } \\
\cline { 2 - 6 } & $\begin{array}{l}\text { Delhi } \\
\text { (India) }\end{array}$ & $\begin{array}{l}\text { Kathmandu } \\
\text { (Nepal) }\end{array}$ & $\begin{array}{l}\text { Karachi } \\
\text { (Pakistan) }\end{array}$ & $\begin{array}{l}\text { Dhaka } \\
\text { (Bangladesh) }\end{array}$ & $\begin{array}{l}\text { Colombo } \\
\text { (SriLanka) }\end{array}$ \\
\hline 1. Coal & 12187.4 & 6537.9 & 1362.0 & 2928.7 & 3686.8 \\
2. Liquid fuels & 9671.2 & 46952.2 & 12424.5 & 2129.4 & 340195.8 \\
3. Natural gas (incl. other gases) & 3141.9 & 519.7 & 24955.9 & 7867.3 & 946.2 \\
4. Biomass & 89.8 & 254199.4 & 1696.3 & 1961.8 & 426199.0 \\
6. Renewables (excl. biomass) & NA & 10210.7 & 0.6 & 0.5 & 48009.8 \\
7. Electricity & 5958.9 & 3792.1 & 594.6 & 484.1 & 18678.6 \\
\hline
\end{tabular}

Table 2. Number of vehicles per capita in the capital cities of South Asia.

\begin{tabular}{llllll}
\hline Vehicle Type & \multicolumn{5}{c}{ Number of Vehicles per capita [Unit: $10^{-3}$ V per capita] } \\
\cline { 2 - 6 } & $\begin{array}{l}\text { Delhi } \\
\text { (India) }\end{array}$ & $\begin{array}{l}\text { Kathmandu } \\
\text { (Nepal) }\end{array}$ & $\begin{array}{l}\text { Karachi } \\
\text { (Pakistan) }\end{array}$ & $\begin{array}{l}\text { Dhaka } \\
\text { (Bangladesh) }\end{array}$ & $\begin{array}{l}\text { Colombo } \\
\text { (Srilanka) }\end{array}$ \\
\hline 1. Motorcycles & 249.09 & 313.19 & 93.97 & 5.15 & 524.11 \\
2. Light duty vehicles-diesel & 18.96 & 77.44 & 7.22 & 0.98 & 760.03 \\
3. Light duty vehicles-gasoline & 65.99 & 54.44 & 16.33 & 0.90 & 1101.21 \\
4. Heavy duty vehicles-diesel & 6.69 & 13.16 & 1.23 & 0.17 & 97.16 \\
6. Electric vehicles & 0.06 & 0.01 & NA & NA & 0.02 \\
7. Other road transport & 111.97 & 33.50 & 16.35 & 3.89 & 29.07 \\
Sum (as per 2020) & 452.76 & 491.72 & 135.10 & 11.09 & 2511.58 \\
\hline
\end{tabular}

Likewise, Delhi has a higher number of total vehicles $\left(13.7 \times 10^{6}\right.$ vehicles), although the vehicles per capita are not the highest of the compared cities (Table 2). However, the imposition of lockdown has resulted into the much lower levels of atmospheric pollutants like $\mathrm{NO}_{\mathrm{x}}, \mathrm{SO}_{\mathrm{x}}$, particulate matters (PM), etc. because most of these pollutants in big cities and high density clusters are emitted from transport (Table 1 ) and industrial (Table 2) sectors (Singh et al., 2020). The comparison in tropospheric $\mathrm{NO}_{2}$ column levels obtained at $0.25^{\circ}$ spatial resolution over South Asia during the last week of March 2019 and 2020 has been shown in Fig. 1, as observed from NASA's open access portal (GIOVANNI). Owing to mobility restrictions, transportation has led to a drastic decrease in $\mathrm{NO}_{2}$ levels in the last week of March, 2020. Lockdown has given a big respite in the form of plummeting air pollution to the megacities which suffer unhealthy pollution load for whole year (Jain and Sharma, 2020). In south Asia, several big cities which are known to have high pollution levels, have recorded an improvement in air quality from the imposition of lockdown as shown in Table 3. We have assessed the capital cities of south Asian countries based on the AQI data obtained from U.S. Embassy and consulate's World Air quality Index Project website (https://waqi.info/). The $1^{\text {st }}$ phase of lockdown was selected as study period (last week of March) due to the strictest and complete lockdown in the region. AQI is an assessment of the air quality using different criteria pollutants. Accordingly, the range of $A Q I$ is divided in different categories. The AQI below 50 is considered to be in good category. Further, an AQI from 51 to 100 is considered as satisfactory, 101 to 200 as moderate, 201 to 300 as poor, 301 to 400 as very poor and 401 to 500 as severe category.

\subsection{India}

As the 21-days lockdown declared by the government on $24^{\text {th }}$ March 2019 to combat the coronavirus pandemic most of the cities have shown a gradual improvement in air quality. As per the central pollution control board (CPCB, India) report, a significant reduction in air pollutants was observed in about 91 cities in the last week of March month leading to an AQI in 'satisfactory' and 'good' category (Dumka et al., 2020; Navinya et al., 2020). Moreover, the number of cities which were recording $A Q I$ in poor to severe category have also came down from $21^{\text {st }}$ March to $29^{\text {th }}$ March 2020. Delhi, which remains among the top polluted megacities in the world, usually battles with the severe issues of air pollution almost throughout the year (Mishra and Kulshrestha, 2017). 

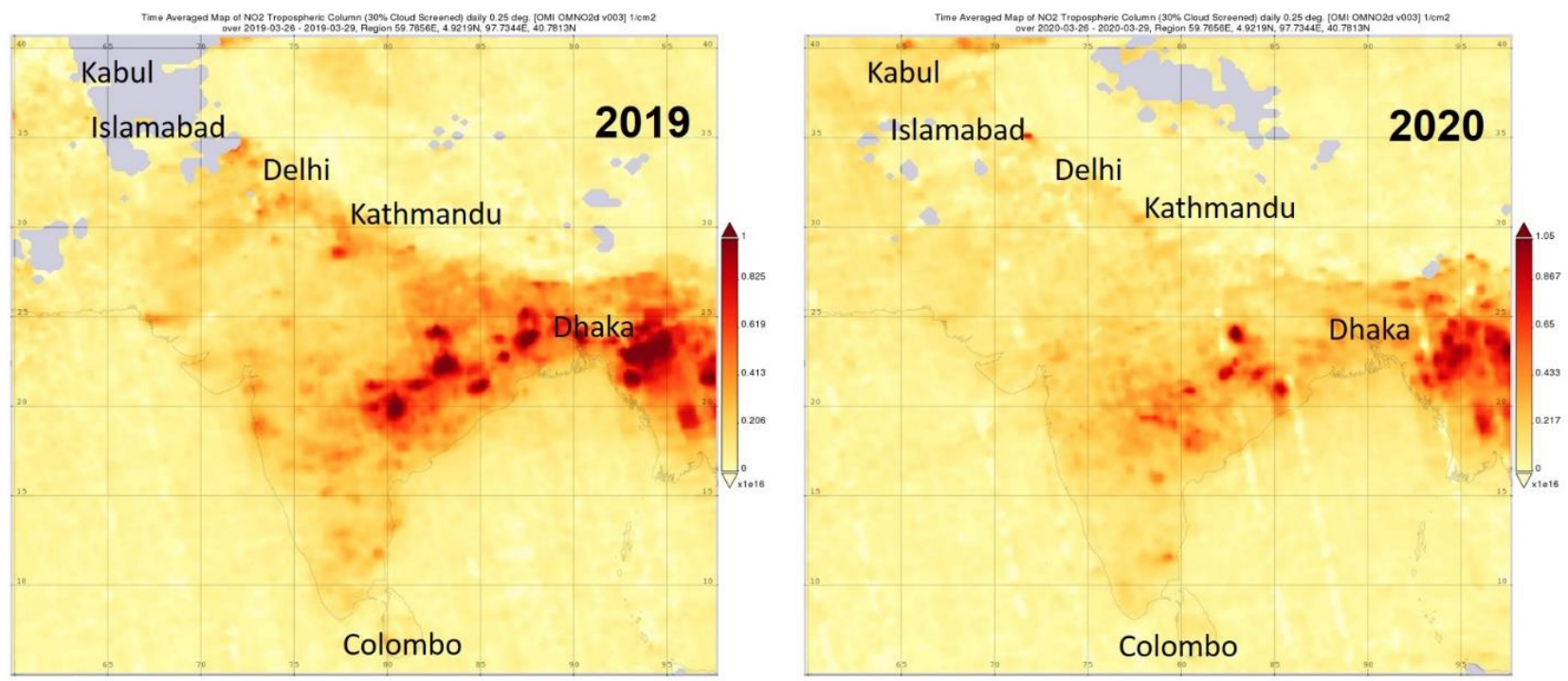

Fig. 1. $\mathrm{NO}_{2}$ column (from the surface to the top of the tropopause) levels (in mol. $\mathrm{cm}^{-2}$ ) over South Asia during the last week $\left(25^{\text {th }}-31^{\text {st }}\right)$ of March 2019 and 2020, respectively.

Table 3. Decrease in AQI just after lockdown (March last week) in South Asia.

\begin{tabular}{llll}
\hline City & Average AQI 2019 & Average AQI 2020 & Reduction in Lockdown \\
\hline Delhi & 147 & 86 & $41 \%$ \\
Islamabad & NA & 80 & NA \\
Dhaka & 192 & 161 & $16 \%$ \\
Kabul & NA & 78 & NA \\
Kathmandu & 142 & 97 & $32 \%$ \\
Colombo & 115 & 77 & $33 \%$ \\
\hline
\end{tabular}

But it has observed a huge reduction (41\%) in AQI in the last week of March, $2020(\mathrm{AQI}=86)$ as compared to March, 2019 ( $\mathrm{AQI}=147$ ) which was clearly attributed to the restrictions on transportation and industrial activities (Table 3, Fig. 2) (Metya et al., 2020). Cities located in Indo Gangetic plain region (northern India) which also suffers severe pollution all through the year have showed a significant improvement in AQI values due to reduction in local contributions (Jain and Sharma, 2020; Mishra and Kulshrestha, 2020). The major contributors of air pollution in India are transport sector, biomass burning, industries, construction activities, power plants and road dust resuspension (Guttikunda et al., 2014; Singh et al., 2016). Furthermore, mining activities, restaurants cooking, landfill sites are certain factors which also add to air pollution load (Ghose, 2007; Jha et al., 2008; Ranjan et al., 2020).

\subsection{Bangladesh}

In order to prevent the spread of virus COVID-19, the Bangladeshi authorities imposed ban on passenger travel via domestic flights, railways and water routes from March 24, 2020 and suspended all public transport from March 26, 2020 (Pavel et al., 2020). However, trucks, and vehicles carrying essential food items, medicine, fuel and other perishable materials were kept out of purview of the lockdown. Though the AQI over Dhaka, the capital city of Bangladesh, have shown a slight improvement (16\%) as compared to previous year yet the air quality remained in the moderate range and unhealthy levels (Fig. 2). Usually, Dhaka records severe pollution levels throughout the year except monsoon and ranks among top 20 most polluted cities in the world (Cheng et al., 2016). Use of coal and wood in brick kilns, heavy industries and very high traffic density in the capital city are the main sources of the pollution. Dhaka has also been reported to receive the outflow of pollutants from densely populated Indo-Gangetic Plain (IGP) region (Salam et al., 2018). In this regard, the sustained lockdown in the major industrial hubs have shown positive impact on the air quality in various parts of Bangladesh (Islam et al., 2021). Phase wise 


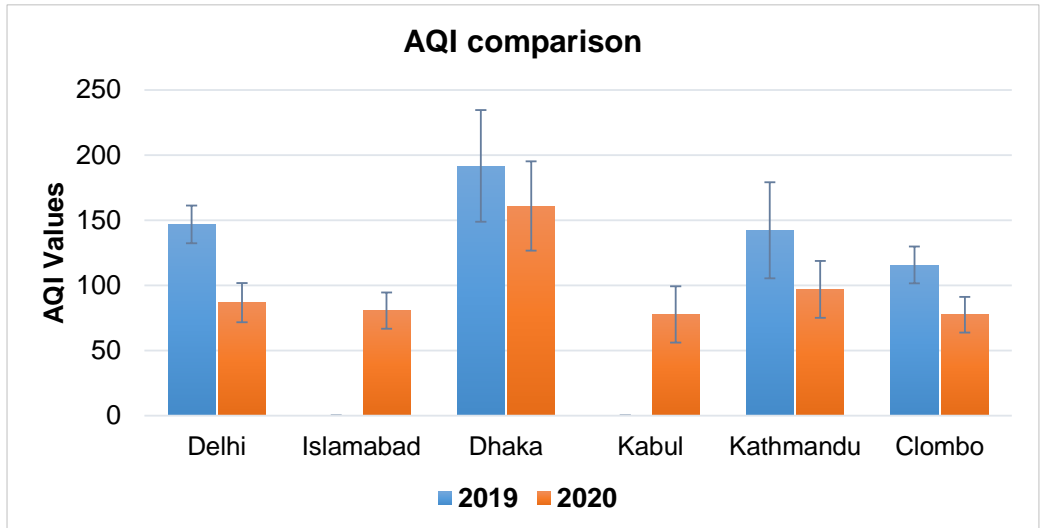

Fig. 2. Air Quality Index of different capital cities of south Asia in the initial phase of lockdown in March $\left(25^{\text {th }}-31^{\text {st }}\right) 2020$ and its comparison in same duration of 2019 (data obtained from U.S. Embassy and consulate's World Air quality Index Project website: https://waqi.info/). Data of March 2019 was not available for Islamabad and Kabul.

lockdown, extended until $30^{\text {th }}$ May, 2020, led to about two third reduction in ambient levels of $\mathrm{SO}_{2}$ and $\mathrm{NO}_{2}$ as compared to 2019 in same duration (Islam et al., 2021). Studies of Dhaka city have also found a significant correlation between air quality parameters and COVID-19 transmission which confirms that full and partial lockdown helped in flattening the infected cases curve (Pavel et al., 2020; Rahman et al., 2020).

\subsection{Pakistan}

Pakistan's AQI levels have improved significantly after the government's order to shut down the factories and transportation facilities to limit the spread of the novel coronavirus. Due to the lack of data and regular monitoring facility the AQI values of Pakistan could not be compared with the previous year's data (Table 3, Fig. 2). While many other countries in the region have shown a considerable improvement in air quality, there is still a long way for undeveloped nations including Pakistan to spread awareness and actively monitoring of air pollutants (Anjum et al., 2021). According to the World Health Organization (WHO), around 60,000 Pakistanis died in 2015 due to the high level of atmospheric fine particles and was the highest death rate in the world due to air pollution (Anjum et al., 2021). The major polluting fuel types in the country are coal combustion, biomass burning and vehicular emissions (Ali and Athar, 2008). Data compiled by the Global Health and Pollution Alliance have found that around 128,000 people die from diseases related to air pollution each year in Pakistan. During the lockdown, ambient air quality has been reported to be improved greatly in Karachi, Islamabad and even Lahore (Khurshied, 2020). The state capital has improved in terms of AQI, with life almost halting to prevent the spread of COVID-19. The city seems to regularly cross the red line of pollution in the summer months with an AQI readings over 300 which is very harmful and in most cases dangerous for humans. However, AQI of various cities is found between 18 and 65 which represents a major improvement in air quality (Khurshied, 2020). According to the air pollution data, the Islamabad city has found to be improved significantly with satisfactory range of AQI $(=80)$ in the last week of March, 2020 i.e., since the imposition of limited movements by the government (Fig. 2). However, lockdown was lifted soon (in the starting of May, 2020) owing to adverse socioeconomic impacts (Ali et al., 2020).

\subsection{Afghanistan}

As per the Afghanistan's Public Health Ministry, the country witness poor air quality all over the year and consequently a large number of human suffer from respiratory related illness including common cold, asthma and other problems associated with lungs. According to the updates provided by Air Visual, an international monitoring organization, air pollution remains at hazardous level in Kabul as observed from the trend of past few years (The diplomat, 2019). The spike in pollution levels is also associated with the mineral dust from the drylands of Middle East 
region. Major sources of the pollution in the capital are the use of low-quality liquid fuel and coal. Kabul has been enlisted with the most polluted cities in the world ranking along with other polluted capitals like Delhi, Beijing, Cairo, etc. According to a survey by the State of Global Air in 2017, about 19,400 deaths in Afghanistan were attributable to the household pollution due to the use of low grade coal, which also accounted to a loss of two years of life expectancy at birth (BS, 2019). However, the recent lockdown have reduced the AQI to satisfactory range $(<100)$, which might be seen as an opportunity to realize and limit the major factors causing air pollution (Fig. 2). Yet the decades of war and conflicts have worsened the Afghanistan's environmental conditions and it's still a huge challenge for them to address these issues.

\subsection{Nepal}

Nearly after a week of the government's imposition of a temporary lockdown since $24^{\text {th }}$ March 2020 across the Nepal to contain the spread of COVID-19, the Kathmandu Valley and other major cities of Nepal have started to witness an improvement in their AQI values (Pant et al., 2020). Kathmandu skies have cleared and air quality has also improved significantly as there is no additional pollution due to the halt of transportation and other activities. Since the lockdown in the country, factors like virtual halt in vehicle movement and closure of industries have shown encouraging impact on air quality (Shrestha et al., 2020). A significant reduction in AQI in last week of March 2020 as compared to 2019 has been observed in Kathmandu (Fig. 2). The shutdown has forced to close all large and small power plants and other industrial facilities, which are the most important factors in burning fossil fuels and emission of nitrogen dioxide and other harmful gases, according to government authorities (Panday and Prinn, 2009). Biomass is one of the major fuel type used for cooking (Table 1) and majorly responsible for adverse health impacts (Shrestha and Shrestha, 2005; Pokhrel et al., 2010). During normal days, the AQI value fluctuates between 150 and 180 in the capital city, which is considered unhealthy (Pant et al., 2020). However, after few days of closure around $27^{\text {th }}$ March 2020 onwards, the AQI in the central areas of the valley was between 50 and 85 (Fig. 2) and AQI reduced by 32\% (Table 3). The situation was similar in the major cities as the lower AQI values of Pokhara and Biratnagar were also observed as 58 and 75, respectively (My Republica, 2020).

\subsection{Sri Lanka}

Sri Lanka's air quality usually hit the above 100 mark on the Air Quality Index as per the National Building and Research Organization (Ranaraja et al., 2019). Despite being coastal country, the continental outflow remains one of the major cause of increased pollution levels in Sri Lanka (Seneviratne et al., 2011). Biomass burning is one of the major fuel type in Colombo, the capital city of Sri Lanka (Table 1) (Nandasena et al., 2010). However, vehicular (Petroleum) and thermal power plants emissions alone reported to be responsible for $60 \%$ air pollution in the country (Ranaraja et al., 2019). Following the stringent curfew, the transport and travel restrictions and closing of industries to prevent COVID-19, a significant decrease has been observed in Colombo's AQI (33\%) in the last week of March, 2020 as compared to previous year (Fig. 2, Table 3). Pollution reduction in Colombo can also be assigned to the lowering of emissions in the nearby continental region.

\section{CONCLUSION}

There has been continuous data observation by various international agencies across the world which have reported an improvement in the air quality due to strict measures taken in all the major polluting sectors during the lockdown. Since, South Asia imparts significant share in coal consumption, number of vehicles and biomass burning, we have observed as high as $\sim 41 \%$ of reduction in AQI levels owing to the imposed restrictions. Apart from sources, interplay between prevailing weather and ambient chemistry also have a crucial role in the regulating the burden and dynamics of atmospheric pollutants which further need to be investigated. The present observations have shown that lockdown enforced in the last week of March, 2020 to prevent COVID-19 outbreak has greatly improved the air quality of South Asian region when compared with the same period in previous year. The lower $\mathrm{AQI}$ and $\mathrm{NO}_{2}$ values were primarily on account of industrial and vehicular emissions reduction but no major changes were observed 
in emission from other sources such as atmospheric dust, biomass burning for cooking, etc. Thus, it can be concluded that cities with greater reduction have more influence from industrial and vehicular emission sources, including halted aircrafts. Since, the restrictions on mobility and other economic activities are not a sustainable solution, the governments had to lift it soon after few weeks of strict lockdown in phase-wise manner. Overall, the lockdown can be seen as an evidence of the benefits which can be reaped by regulating air emissions and introducing new policies based on country/region-wise dominant anthropogenic sources.

\section{RECOMMENDATIONS}

1. Since strict lockdown cannot be seen as a long-term solution, the policy makers need to include measures such as restricting some industrial emissions through rotating operational days, switching over to cleaner energy options and setting up new air quality standards.

2. To the extent possible for each country, regulatory bodies should ensure deployment of all the necessary pollution control equipment in vehicular and industrial sectors and to ensure their operation as per the regulatory norms.

3. There is need to avoid biomass burning for cooking and wintertime heating, especially in south Asian countries.

4. There is need to stop crop residue burning. Instead we need to opt non-burning methods such as establishing bio-refineries and implementation of Happy Seeder Technology (HST). HST helps in mixing residues of previous crops with soil to enhance nutrient content while sowing new seeds, without burning. Thus, it minimizes crop residue burning in the fields.

5. Work From Home (WFH) has shown us the way of sustainable life. It should be allowed in all sectors as much as possible. However, we need to formulate new regulations to make WFH more efficient and systematic.

6. A Rapid Public Transport system across south Asia will help in reducing air pollution.

7. Battery driven vehicles need to be promoted. However, capacity for solar and wind power need to be built with out delay as these are the future back bone of energy supply in tropics.

8. School buses are significant contributors of air pollution. In order to control emissions from these buses, we need to make regulations for admitting a child in primary school within $5 \mathrm{~km}$ circle from the residence.

9. The COVID-19 situation has provided us the answer to the violating levels of $\mathrm{PM}_{10}$ and $\mathrm{PM}_{2.5}$ in India especially in north India where the dominance of atmospheric dust substantially contributes to the particulate levels. Similarly, countries like Afghanistan and Pakistan also suffer from the high levels of mineral dust, apart from other sources. Hence, there is need to control suspended dust from roads, open fields and construction sector.

10. The complete lockdown period has indicated background ambient values of pollutants which are considered as 'new normal' for the South Asian region; there is a need to re-define new National Ambient Air Quality Standards (NAAQS) in particular for the $\mathrm{PM}_{10}$ and $\mathrm{PM}_{2.5}$.

11. In order to quantify the share of air pollution from long range transport and trans-boundary routes, we need an inter-state agency under the South Asian Association for Regional Cooperation (SAARC) framework.

\section{ACKNOWLEDGEMENT}

The financial support received from CSIR as SRF to Dr Manisha Mishra is gratefully acknowledged.

\section{REFERENCES}

Ali, M., Athar, M. (2008). Air pollution due to traffic, air quality monitoring along three sections of National Highway N-5, Pakistan, in: Environmental Monitoring and Assessment, Springer, pp. 219-226. https://doi.org/10.1007/s10661-007-9677-3

Ali, S.M., Malik, F., Anjum, M.S., Siddiqui, G.F., Anwar, M.N., Lam, S.S., Nizami, A.S., Khokhar, M.F. 
(2020). Exploring the linkage between $\mathrm{PM}_{2.5}$ levels and COVID-19 spread and its implications for socio-economic circles. Environ. Res. 193, 110421. https://doi.org/10.1016/j.envres.2020.1 10421

Anjum, M.S., Ali, S.M., Imad-ud-din, M., Subhani, M.A., Anwar, M.N., Nizami, A.S., Ashraf, U., Khokhar, M.F. (2021). An emerged challenge of air pollution and ever-increasing particulate matter in Pakistan; A critical review. J. Hazard. Mater. 402, 123943. https://doi.org/10.1016/ j.jhazmat.2020.123943

Babu, S.R., Rao, N.N., Kumar, S.V., Paul, S., Pani, S.K. (2020). Plausible role of environmental factors on COVID-19 transmission in the megacity Delhi, India. Aerosol Air Qual. Res. 20, 20752084. https://doi.org/10.4209/aaqr.2020.06.0314

Baldasano, J.M. (2020). COVID-19 lockdown effects on air quality by $\mathrm{NO}_{2}$ in the cities of Barcelona and Madrid (Spain). Sci. Total Environ. 741, 140353. https://doi.org/10.1016/j.scitotenv.2020. 140353

Bao, R., Zhang, A. (2020). Does lockdown reduce air pollution? Evidence from 44 cities in northern China. Sci. Total Environ. 731, 139052. https://doi.org/10.1016/j.scitotenv.2020.139052

Bolaño-Ortiz, T.R., Pascual-Flores, R.M., Puliafito, S.E., Camargo-Caicedo, Y., Berná-Peña, L.L., Ruggeri, M.F., Lopez-Noreña, A.I., Tames, M.F., Cereceda-Balic, F. (2020). Spread of COVID-19, meteorological conditions and air quality in the city of Buenos Aires, Argentina: Two facets observed during its pandemic lockdown. Atmosphere 11, 1045. https://doi.org/10.3390/atm os11101045

Cameletti, M. (2020). The effect of corona virus lockdown on air pollution: Evidence from the City of brescia in Lombardia Region (Italy). Atmos. Environ. 239, 117794. https://doi.org/10.1016/j. atmosenv.2020.117794

Cheng, Z., Luo, L., Wang, S., Wang, Y., Sharma, S., Shimadera, H., Wang, X., Bressi, M., de Miranda, R.M., Jiang, J., Zhou, W., Fajardo, O., Yan, N., Hao, J. (2016). Status and characteristics of ambient $\mathrm{PM}_{2.5}$ pollution in global megacities. Environ. Int. 89-90, 212-221. https://doi.org/10. 1016/j.envint.2016.02.003

Cohen, A.J., Brauer, M., Burnett, R., Anderson, H.R., Frostad, J., Estep, K., Balakrishnan, K., Brunekreef, B., Dandona, L., Dandona, R., Feigin, V., Freedman, G., Hubbell, B., Jobling, A., Kan, H., Knibbs, L., Liu, Y., Martin, R., Morawska, L., Pope, C.A., ... Forouzanfar, M.H. (2017). Estimates and 25-year trends of the global burden of disease attributable to ambient air pollution: An analysis of data from the Global Burden of Diseases Study 2015. Lancet 389, 1907-1918. https://doi.org/10.1016/S0140-6736(17)30505-6

Cui, Y., Zhang, Z.F., Froines, J., Zhao, J., Wang, H., Yu, S.Z., Detels, R. (2003). Air pollution and case fatality of SARS in the People's Republic of China: An ecologic study. Environ. Health 2, 1-5. https://doi.org/10.1186/1476-069x-2-15

Dhaka, S.K., Chetna, Kumar, V., Panwar, V., Dimri, A.P., Singh, N., Patra, P.K., Matsumi, Y., Takigawa, M., Nakayama, T., Yamaji, K., Kajino, M., Misra, P., Hayashida, S. (2020). PM2.5 diminution and haze events over Delhi during the COVID-19 lockdown period: An interplay between the baseline pollution and meteorology. Sci. Rep. 10, 13442. https://doi.org/10.1038/ s41598-020-70179-8

Dumka, U.C., Kaskaoutis, D.G., Verma, S., Ningombam, S.S., Kumar, S., Ghosh, S. (2020). Silver linings in the dark clouds of COVID-19: Improvement of air quality over India and Delhi metropolitan area from measurements and WRF-CHIMERE model simulations. Atmos. Pollut. Res. 12, 225-242. https://doi.org/10.1016/j.apr.2020.11.005

Ghose, M.K. (2007). Generation and quantification of hazardous dusts from coal mining in the Indian context. Environ. Monit. Assess. 130, 35-45. https://doi.org/10.1007/s10661-006-9451-y

Grahame, T.J., Klemm, R., Schlesinger, R.B. (2014). Public health and components of particulate matter: The changing assessment of black carbon. J. Air Waste Manage. Assoc. 64, 620-660. https://doi.org/10.1080/10962247.2014.912692

Grandjean, P. (2013). Only One Chance: How environmental pollution impairs brain development, Only One Chance.

Guttikunda, S.K., Goel, R., Pant, P. (2014). Nature of air pollution, emission sources, and management in the Indian cities. Atmos. Environ. 95, 501-510. https://doi.org/10.1016/j.atmo senv.2014.07.006

Hashim, B.M., Al-Naseri, S.K., Al-Maliki, A., Al-Ansari, N. (2021). Impact of COVID-19 lockdown on 
$\mathrm{NO}_{2}, \mathrm{O}_{3}, \mathrm{PM}_{2.5}$ and $\mathrm{PM}_{10}$ concentrations and assessing air quality changes in Baghdad, Iraq. Sci. Total Environ. 754, 141978. https://doi.org/10.1016/j.scitotenv.2020.141978

Höglund-Isaksson, L., Gómez-Sanabria, A., Klimont, Z., Rafaj, P., Schöpp, W. (2020). Technical potentials and costs for reducing global anthropogenic methane emissions in the 2050 timeframe - results from the GAINS model. Environ. Res. Commun. 2, 025004. https://doi.org/ 10.1088/2515-7620/ab7457

Islam, M.S., Tusher, T.R., Roy, S., Rahman, M. (2021). Impacts of nationwide lockdown due to COVID-19 outbreak on air quality in Bangladesh: A spatiotemporal analysis. Air Qual. Atmos. Health 14, 351-363. https://doi.org/10.1007/s11869-020-00940-5

Jain, S., Sharma, T. (2020). Social and travel lockdown impact considering coronavirus disease (Covid-19) on air quality in megacities of india: Present benefits, future challenges and way forward. Aerosol Air Qual. Res. 20, 1222-1236. https://doi.org/10.4209/aaqr.2020.04.0171

Janssen, N.A.H., Hoek, G., Simic-Lawson, M., Fischer, P., van Bree, L., Brink, H. Ten, Keuken, M., Atkinson, R.W., Ross Anderson, H., Brunekreef, B., Cassee, F.R. (2011). Black carbon as an additional indicator of the adverse health effects of airborne particles compared with $\mathrm{PM}_{10}$ and PM2.5. Environ. Health Perspect. 119, 1691-1699. https://doi.org/10.1289/ehp.1003369

Jha, A.K., Sharma, C., Singh, N., Ramesh, R., Purvaja, R., Gupta, P.K. (2008). Greenhouse gas emissions from municipal solid waste management in Indian mega-cities: A case study of Chennai landfill sites. Chemosphere 71, 750-758. https://doi.org/10.1016/j.chemosphere.2007.10.024

Khurshied, A.K. (2020). Air quality index with particulate matter $\left(\mathrm{PM}_{2.5}\right)$ improved after national lockdown during COVID-19 outbreak across Pakistan. Open Access J. Biog. Sci. Res. 3. https://doi.org/10.46718/jbgsr.2020.03.000065

Kumar, P., Hama, S., Omidvarborna, H., Sharma, A., Sahani, J., Abhijith, K. V., Debele, S.E., ZavalaReyes, J.C., Barwise, Y., Tiwari, A. (2020). Temporary reduction in fine particulate matter due to 'anthropogenic emissions switch-off' during COVID-19 lockdown in Indian cities. Sustain. Cities Soc. 62, 102382. https://doi.org/10.1016/j.scs.2020.102382

Menut, L., Bessagnet, B., Siour, G., Mailler, S., Pennel, R., Cholakian, A. (2020). Impact of lockdown measures to combat Covid-19 on air quality over western Europe. Sci. Total Environ. 741, 140426. https://doi.org/10.1016/j.scitotenv.2020.140426

Metya, A., Dagupta, P., Halder, S., Chakraborty, S., Tiwari, Y.K. (2020). COVID-19 lockdowns improve air quality in the south-east Asian Regions, as seen by the remote sensing satellites. Aerosol Air Qual. Res. 20, 1772-1782. https://doi.org/10.4209/aaqr.2020.05.0240

Mishra, M., Kulshrestha, U. (2017). Chemical characteristics and deposition fluxes of dust-carbon mixed coarse aerosols at three sites of Delhi, NCR. J. Atmos. Chem. 74, 399-421. https://doi.org/10.1007/s10874-016-9349-1

Mishra, M., Kulshrestha, U.C. (2020). Extreme air pollution events spiking ionic levels at urban and rural sites of Indo-Gangetic Plain. Aerosol Air Qual. Res. 20, 1266-1281. https://doi.org/10. 4209/aaqr.2019.12.0622

Nakada, L.Y.K., Urban, R.C. (2020). COVID-19 pandemic: Impacts on the air quality during the partial lockdown in São Paulo state, Brazil. Sci. Total Environ. 730, 139087. https://doi.org/10. 1016/j.scitotenv.2020.139087

Nandasena, Y.L.S., Wickremasinghe, A.R., Sathiakumar, N. (2010). Air pollution and health in Sri Lanka: A review of epidemiologic studies. BMC Public Health 10, 1-14. https://doi.org/10.118 6/1471-2458-10-300

NASA (2020). Airborne Particle Levels Plummet in Northern India. NASA Earth Observatory.

Navinya, C., Patidar, G., Phuleria, H.C. (2020). Examining effects of the COVID-19 national lockdown on ambient air quality across urban India. Aerosol Air Qual. Res. 20, 1759-1771. https://doi.org/10.4209/aaqr.2020.05.0256

Panday, A.K., Prinn, R.G. (2009). Diurnal cycle of air pollution in the Kathmandu Valley, Nepal: Observations. J. Geophys. Res. 114, D09305. https://doi.org/10.1029/2008JD009777

Pani, S.K., Wang, S.H., Lin, N.H., Chantara, S., Lee, C. Te, Thepnuan, D. (2020). Black carbon over an urban atmosphere in northern peninsular Southeast Asia: Characteristics, source apportionment, and associated health risks. Environ. Pollut. 259, 113871. https://doi.org/10.1 016/j.envpol.2019.113871

Pant, B.P., Mishra, A., Shakya, S., Poudyal, K.N. (2020). Impact of COVID-19 lockdown on Particulate Matter $\left(\mathrm{PM}_{2.5}\right)$ concentration in Kathmandu, Nepal. 
Patel, H., Talbot, N., Salmond, J., Dirks, K., Xie, S., Davy, P. (2020). Implications for air quality management of changes in air quality during lockdown in Auckland (New Zealand) in response to the 2020 SARS-CoV-2 epidemic. Sci. Total Environ. 746, 141129. https://doi.org/10.1016/j.s citotenv.2020.141129

Pavel, R.S., Salam, A., Yesmin, M., Ahsan, N., Zaman, S.U., Jeba, F. (2020). Impact and correlation of air quality and climate variables with COVID-19 morbidity and mortality in Dhaka, Bangladesh medRxiv September 2020. medRxiv 2020.09.12.20193086. https://doi.org/10.110 1/2020.09.12.20193086

Pokhrel, A.K., Bates, M.N., Verma, S.C., Joshi, H.S., Sreeramareddy, C.T., Smith, K.R. (2010). Tuberculosis and indoor biomass and kerosene use in Nepal: A case-control study. Environ. Health Perspect. 118, 558-564. https://doi.org/10.1289/ehp.0901032

Rahman, M.S., Azad, M.A.K., Hasanuzzaman, M., Salam, R., Islam, A.R.M.T., Rahman, M.M., Hoque, M.M.M. (2020). How air quality and COVID-19 transmission change under different lockdown scenarios? A case from Dhaka city, Bangladesh. Sci. Total Environ. 762, 143161. https://doi.org/10.1016/j.scitotenv.2020.143161

Ranaraja, C.D.M.O., Arachchige, U.S.P.R., Rasenthiran, K. (2019). Environmental pollution and its challenges in Sri Lanka. Int. J. Sci. Technol. Res. 8, 417-417.

Ranjan, A.K., Patra, A.K., Gorai, A.K. (2020). Effect of lockdown due to SARS COVID-19 on aerosol optical depth (AOD) over urban and mining regions in India. Sci. Total Environ. 745, 141024. https://doi.org/10.1016/j.scitotenv.2020.141024

Rodríguez-Urrego, D., Rodríguez-Urrego, L. (2020). Air quality during the COVID-19: PM2.5 analysis in the 50 most polluted capital cities in the world. Environm. Pollut. 266, 115042. https://doi.org/10.1016/j.envpol.2020.115042

Salam, A., Salam, A. (2018). Long Term Air quality Status at a Southeast Asian Mega City and an IGP outflow location: Aerosol Chemical Characterization and Optical Properties. AGUFM 2018, A41G-3034.

Schraufnagel, D.E., Balmes, J.R., Cowl, C.T., De Matteis, S., Jung, S.H., Mortimer, K., Perez-Padilla, R., Rice, M.B., Riojas-Rodriguez, H., Sood, A., Thurston, G.D., To, T., Vanker, A., Wuebbles, D.J. (2019). Air pollution and noncommunicable diseases. A review by the forum of international respiratory societies' environmental committee, Part 1: The damaging effects of air pollution. Chest 155, 409-416. https://doi.org/10.1016/j.chest.2018.10.042

Seneviratne, M.C.S., Waduge, V.A., Hadagiripathira, L., Sanjeewani, S., Attanayake, T., Jayaratne, N., Hopke, P.K. (2011). Characterization and source apportionment of particulate pollution in Colombo, Sri Lanka. Atmos. Pollut. Res. 2, 207-212. https://doi.org/10.5094/APR.2011.026

Shakoor, A., Chen, X., Farooq, T.H., Shahzad, U., Ashraf, F., Rehman, A., Sahar, N. e., Yan, W. (2020). Fluctuations in environmental pollutants and air quality during the lockdown in the USA and China: Two sides of COVID-19 pandemic. Air Qual. Atmos. Health 13, 1335-1342. https://doi.org/10.1007/s11869-020-00888-6

Shrestha, A.M., Shrestha, U.B., Sharma, R., Bhattarai, S., Tran, H.N.T., Rupakheti, M. (2020). Lockdown caused by COVID-19 pandemic reduces air pollution in cities worldwide. https://doi.org/10.31223/osf.io/edt4j

Shrestha, I.L., Shrestha, S.L. (2005). Indoor air pollution from biomass fuels and respiratory health of the exposed population in Nepalese households. Int. J. Occup. Environ. Health 11, 150-160. https://doi.org/10.1179/oeh.2005.11.2.150

Singh, R., Kulshrestha, M.J., Kumar, B., Chandra, S. (2016). Impact of anthropogenic emissions and open biomass burning on carbonaceous aerosols in urban and rural environments of IndoGangetic Plain. Air Qual. Atmos. Health 9, 809-822. https://doi.org/10.1007/s11869-015-0377-9

Singh, V., Singh, S., Biswal, A., Kesarkar, A.P., Mor, S., Ravindra, K. (2020). Diurnal and temporal changes in air pollution during COVID-19 strict lockdown over different regions of India. Environ. Pollut. 266, 115368. https://doi.org/10.1016/j.envpol.2020.115368

Venter, Z.S., Aunan, K., Chowdhury, S., Lelieveld, J. (2020). COVID-19 lockdowns cause global air pollution declines. Proc. Natl. Acad. Sci. 117, 202006853. https://doi.org/10.1073/pnas.20068 53117

Wang, Yunjie, Wen, Y., Wang, Yue, Zhang, S., Zhang, K.M., Zheng, H., Xing, J., Wu, Y., Hao, J. (2020). Four-month changes in air quality during and after the COVID-19 lockdown in six megacities in China. Environ. Sci. Technol. Lett. 7, 808. https://doi.org/10.1021/acs.estlett.0c00605 